\title{
EXISTENTIAL DEFINITION AT THE END OF THE AMERICAN ROAD
}

\author{
Zabriskie Point (1970), Vanishing Point (1971), \\ The Gauntlet (1977)
}

The mountains come first.... The traveler tries to go round the obstacle, to move at ground level, from plain to plain, from valley to valley. Sooner or later, he is obliged to travel through certain gorges and mountain passes of sinister repute, but he resorts to them as little as possible.

-Fernand Braudel, The Mediterranean and the Mediterranean World in the Age of Philip /I (1972)

"[C]ertain gorges and mountain passes of sinister repute..." Could there be a better description of parts of the American landscape viewers see in three films that, each in its own way, landmarked the cinema of the 1970s? Michelangelo Antonioni's first (and last) foray into filmmaking in America, Zabriskie Point is remembered as an ambitious but incoherent failure, a visually impressive but superficial attempt to capture the California zeitgeist at the end of the 1960s just as it was about to crash and burn at the Altamont Music Festival. In contrast, Richard Sarafian's Vanishing Point soon achieved cult film status. As played by Barry Newman, the character of Kowalski-his first name is never used-remains the quintessential 1970s anti-hero, easily displacing such other claimants to the title as Gene Hackman's Jimmy Doyle in The French Connection (1971), Steve McQueen's Doc McCoy in The Getaway (1972), and Robert De Niro's Travis Bickle in Taxi Driver (1976). The Gauntlet, directed by and starring Clint Eastwood, occupies a middle ground, allowing Eastwood to deviate from his formulaic "Dirty Harry" character while at the same time reprising the strong, stoic 'outsider' type on which he had
James). Ward Cedar Crest College, USA

(D) 
based his career since the 1960s. Unlike the "Dirty Harry" films, in The Gauntlet there are no criminals or psychopaths who have to be brought to justice; instead, the criminality resides in high places where, ultimately, retribution and revenge are exacted.

As a genre, the road movie is so well established in American filmography that it requires no lengthy explication here. ${ }^{1}$ A growing academic and critical literature continues to accumulate, and new interventions appear on the screen with some regularity (Cohan and Hark 1997; Sargeant and Watson 1999; Laderman 2002; Borden 2012; Archer 2016; Alford 2018). At the same time, the concept has become so elastic that its origins in the Hollywood of the 1960s and 1970s-and especially among so-called 'independent' filmmakers-threaten to become obscured. Adapted to other geographic and cultural settings, even the essential characteristics of high-speed automobiles, rebellious or 'loner' protagonists, and downbeat if not disastrous endings seem to dissolve (Duarte and Corrigan 2018). Simultaneously, a different kind of road movie, entirely urban in its locations and claustrophobic rather than free-wheeling in its mood-yet still possessing the key elements of alienation and anti-social exclusion-has won critical acclaim and breathed new life into the all too often self-reflexive genre of post-noir and neo-noir filmmaking. ${ }^{2}$ One recent essay has called into question whether the road movie, defined by movement, speed, and distance, remains a functional cinematic genre, or-indeed-if it ever was (Hurault-Paupe 2014).

CarCulture(s) Machines, Roads Mythologies

My purpose in this essay is to discuss three films from the 'classic' era of the road movie, each of which made a distinctive contribution in defining the existential anti-hero in the cultural consciousness of the time. That two of the three are enmeshed in extra-diegetic circumstances surrounding their leading players only adds to their emblematic presence in what was arguably the most formative decade in American moviemaking (Biskind 1998; Godfrey 2018).

1. Significantly, the other place where the road movie quickly achieved an iconic presence was Australia, not only with Ceorge Miller's four (to date) Mad Max films but also with Wim Wenders's underappreciated Until the End of the World (1991). The topographical equivalencies, as well as the sociocultural affinities, are persuasive (see Melbye 2010: 199-122; Thomas 2021).

2. Examples include Drive, directed by Nicholas Refn (2011); Nightcrawler, directed by Dan Gilroy (2014); and Baby Driver, directed by Edgar Wright (2017). 
If the road movies of the 1970s carried the themes and tropes established by Bonnie and Clyde (1967) and Easy Rider (1969) to their aesthetic as well as logical conclusion, their importance to the construct of American cultural history in the twentieth century speaks for itself. ${ }^{3}$ In particular, in their sympathetic exploitation of the almost limitless spatiality of the American Southwest, the three films discussed are artifacts of an era whose reproducibility today owes more to contemporary cinematic technology than to 'real-life' filmmaking. High-speed chases, the cult of the car (especially the muscle car), and the romantic allure of the open highway all seem to be vanishing in the rear-view mirror in the new age of self-driving vehicles, automated highways, and twenty-four-hour video surveillance of every intersection, tollbooth, and parking lot. Geography has been banished by cell phone technology, speed has succumbed to universal congestion, and the wide open spaces of the North American continent are being rendered impassable by climatological catastrophe.

\footnotetext{
"WHEN IT GETS DOWN TO IT YOU HAVE TO CHOOSE ONE SIDE OR THE OTHER"-MARK TO DARIA, IN ZABRISKIE POINT
}

Flush with the critical and commercial success of Red Desert (1964) and Blow-Up (1967), Michelangelo Antonioni was granted exceptional concessions by the MGM brass to make a film that would explore the political and social conflicts that were tearing America apart at the end of the 1960s-a $\$ 3$ million budget which eventually doubled, extended location shooting in Death Valley, complete editorial control, and the casting of two unknowns as his lead characters. Initially conceived by Antonioni and his erstwhile screenwriter Sam Shepard to be an essay on the desolation of the American environment, the project became increasingly political in character as the director witnessed the clashes between police and protestors at the Democratic Convention in Chicago in August 1968 and then spent time with student radicals on uni-

3. Other examples are Two-Lane Blacktop, directed by Monte Hellman (1971) and Dirty Mary, Crazy Larry, directed by John Hough (1974). Period films in which car chases are highlighted but are not the primary focus-e.g., Peter Yates's Bullit (1968), William Friedkin's The French Connection (1971), and Sam Peckinpah's The Cetaway (1972)-are excluded here. 
versity campuses in Southern California. A protracted shooting sequence, from September 1968 through May 1969, together with Antonioni's meetings with representatives of the Black Panther Party, further attenuated the film's original focus. Police brutality, corporate greed, and racism were all layered in as the script went through a series of revisions, with the result that on its release most critics found it saturated with an ideologically-driven politics whose credibility was already eroded beyond repair (Pomerance 2011: 157-98; Behlil 2018: 149-64). Not surprisingly, Jean-Luc Godard had fallen into the same trap with One Plus One/Sympathy for the Devil (1968), where his attempt to reference black power politics came off as little better than a caricature. With box-office receipts under \$1 million, Zabriskie Point was a serious disappointment to MGM. The major studios had already begun to lose interest in the youth rebellion of the late 1960s, which proved as short-lived as its critics had predicted. As the most militant segments of 'The Movement' turned to violence and terrorism, a film that appeared to celebrate wanton destruction-however codified in anti-capitalist and anti-consumerist terms-stood little chance of earning plaudits from mainstream audiences (Bodroghkozy 2002). Today, with its politics largely forgotten, Antonioni's 'American film' can be viewed through a different lens. Rejecting its reputation as an anachronistic curiosity, in 2006 Matthew Gandy observed that "[t]he Italian filmmaker's excoriating yet

CarCulture(s) Machines, Roads Mythologies obtuse critique of American society has subsequently acquired something of a cult status in its guise as an existentialist desert drama rather than in its originally intended role as a countercultural representation of impending political and social revolution" (316).

To give Antonioni credit, the agit-prop session that opens Zabriskie Point, with a group of Black Panthers led by Kathleen Cleaver quarreling over the correct theoretical line with some SDStype students, does as good a job in ten minutes of demolishing the self-referential and self-delusional politics of the late 1960s as Sam Green's and Bill Siegel's 2002 documentary The Weather Underground does in ninety minutes. Caught by the camera, we get one flash of Leninist conviction from Mark (Mark Frechette), a campus hanger-on who declares-as he stomps out of the meet- 
ing-"I'm willing to die. But not out of boredom."4 After buying a pistol in a LA gun shop, Mark is inadvertently involved in a clash between black protestors and the police. Fearing that he may face charges when a policeman is shot, Mark steals a Cessna 210 twin-seater from an unguarded airport and takes off into the desert. His escape brings him into contact with Daria (Daria Halprin), a part-time secretary working for a high-end property development company who is driving from LA to Phoenix in a 1950s Buick sedan. Daria's boss (Rod Taylor) has a high-modernist house in the desert hills where she is expected to join him. Following an extended aerial flirtation that looks like a parody of the crop-duster chase in Alfred Hitchcock's North by Northwest (1959), Daria gives Mark a ride in pursuit of some gas. ${ }^{5}$ More by chance than deliberation, they end up in Death Valley. A lengthy sequence of romantic play among the desert caves and ravines finally brings Mark and Daria to the film's titular location, the lowest spot in the continental US. What follows, as the two get down to serious lovemaking, is the film's most criticized, and frequently ridiculed, episode, a communal love-in with dozens of semi-naked young people, members of the experimental Open Theater group, twisting, turning, and embracing in the sand and dust until they literally fuse with the otherworldly landscape. Returning to reality, Mark and Daria go their separate ways. He flies back to LA and she resumes her drive to Arizona. Landing at the same airport where he had hijacked the plane, Mark is gunned down in the cockpit before he even has a chance to plead his case.

Through his exasperation with privileged college kids playing at being revolutionaries and his run-in with the police, Mark has been effectively depoliticized. His flight into the desert and his dal-

4. The Lenin reference is to the Bolshevik leader's rejoinder to the assertion made by a Menshevik spokesman at the First All-Russian Congress of Soviets in June 1917 that there was, at the moment, no revolutionary party prepared to take power; Lenin, "There is such a party!"

5. Before her encounter with Mark, Daria's stopover in a derelict desert town introduces an element of random menace into her otherwise semi-idyllic drive. For the practiced viewer, the gang of feral boys who surround and threaten her might recall the murder of the homosexual poet Sebastian in Joseph Mankiewicz's Suddenly, Last Summer (1959), from the Tennessee Williams one-act play of the same name. 
CarCulture(s) Machines, Roads Mythologies

liance with Daria have made him a generational outsider, even if he shared in Daria's vision of the group grope at Zabriskie Point. ${ }^{6}$ Initially apolitical in the hippie mode, Daria is radicalized when she hears a news broadcast reporting Mark's death at the airport. Arriving at her boss's home and deflecting his attentions, she wanders through the antiseptic spaces-a combination of natural forms and sleek modernist architecture-until, without a word, she returns to the Buick and drives back into the desert. In the words of a recent essay, it is as though her abrupt departure is driven by some unspoken conviction, a realization that the "hypermodern luxury mansion" has already "absorbed the land of the desert architectonically" (Lie2015: 274). Stopping thecar and getting out, Daria turns back to witness a massive explosion that disintegrates the house and all its contents. Filmed using seventeen graduated camera locations, the explosion sequence, repeated over and over at always closer range, remains one of Antonioni's most celebrated cinematic achievements; even those most hostile to the film are willing to acknowledge the surreal beauty of the images. Like the love-in at Zabriskie Point, is the explosion of the hilltop mansion nothing more than Daria's fantasy? We have seen no evidence that Daria was carrying explosives in the Buick and taking the time to secrete them inside the house. In a revaluation of the film for the British Film Institute, cinema scholar Angelo Restivo concludes that one "does not imagine that Daria is driving off to join a terrorist cell" (95) But her radical alienation from the company for which she works and the lifestyle it markets so aggressively suggests just that. Is it that difficult to imagine Daria today as an eco-terrorist or as a masked streetfighter in an anarchist protest against the WTO and the IMF?

\footnotetext{
6. Ironically, Mark Frechette's personal story in large part paralleled his character's trajectory in the film. A member of the Boston-based Manson-like cult around Mel Lyman when Antonioni cast him, Frechette made a couple of more films that went nowhere before getting himself arrested in a botched bank robbery. Sentenced to a several-year prison term, he was found dead in the exercise room in September 1975. The circumstances of his death remain murky (Tweedle 2010).

7. In an essay originally published in 2000, Fiona Villella wrote that Daria's suggestion of a smile at the end of the film functions as a confirmation of her political radicalization (Villella 2015).
} 
"I'M HEADING FOR FRISCO"-KOWALSKI TO THE HITCHHIKER, IN VANISHING POINT (UK VERSION)

Effectively dumped by its distributor Twentieth CenturyFox only to become an unexpected box-office hit especially on the drive-in circuit, Vanishing Point now has to carry a lot of theoretical weight. For example, in 2007 literature scholar John Beck wrote that the film "shed[s] critical light on contemporary issues concerning speed and technology, the imbrication of the individual in systems of militarization and surveillance, and the limits of resistance." "By following the logic of the road movie to its terminus," Beck continues, "[Vanishing Point] pushes into and beyond the affirmative tendencies of the genre in its conventional and counter-cultural modes, and in doing so probes the limits of American fictions of legitimate power" (36-37). Reading the film today presupposes a familiarity with the work of Paul Virilio and Jean Baudrillard-at a minimum-and predicates a lengthy discussion of the man-machine nexus, the hyper-aestheticization of speed and violence, and the relation of neurochemical stimulation and hypnagogic regression, i.e., flashbacks (see, e.g., Pascoe 2002; Zendy 2013). Whether director Richard Sarafian or screenwriter Guillermo Cabrera Infante, or for that matter Barry Newman himself, had any of this in mind when they were making the film is questionable. More likely they were remembering the first hundredmile-an-hour trip Sal Paradise and Dean Moriarty share in Jack Kerouac's On the Road (1957), delivering a Cadillac sedan from Denver to Chicago in record time and nearly wrecking it in the process (Kowalski's route is supposed to take him from Denver to San Francisco). Unlike fellow speed freak and world-class ladies' man Dean, however, Kowalski is the ultimate enigmatic loner; no rapturous disquisitions on the glories of the road from him, and he passes on the offer of sex from a naked blonde on a motorcycle. He is not given to the barely articulate efforts at self-explanation we know so well from Marlon Brando's Johnny Strabler in The Wild One (1953) and James Dean's Jim Stark in Rebel Without a Cause (1955), nor does he reveal the occasional moment of insight that we get from Peter Fonda's Captain America character in Easy Rider (in marked contrast to the stupefaction exhibited by Dennis Hopper's stoner companion Billy). Kowalski gives away almost 
nothing, save perhaps a sense of irony; as an existentialist icon he's closer to Camus than he is to Dostoyevsky. It is not clear, as lain Borden observes in his discussion of Vanishing Point, that Kowalski even enjoys driving which, after all, is all that he does (114-115). While he outruns everyone who tracks or chases him, he is little more than a spectator on the disjointed scenes that flash by his window. ${ }^{8}$

With its elliptical structure-it begins with an ending that is later revealed to be false-Vanishing Point can seem to be one long amphetamine-fueled rush, intercut with a handful of flashbacks that tell us all we ever learn about Kowalski. Once a relative straight-arrow, a Vietnam vet, ex-policeman, and former motorcycle and stockcar racer, Kowalski lost it all when, ignoring his warnings, his girlfriend died in a surfing accident. His driving skills remain undiminished, although there is one quick flashback image of a wrecked race car that unsettles us because it suggests the shared carnage of man and machine that will conclude the film. ${ }^{9}$ Some accounts of Vanishing Point refer to Kowalski's nihilistic addiction to speed, but that is only half right. He is addicted to speed, in both senses, but he does not lack a scale of values. Each time he outdrives a pursuing policeman, resulting in an off-road crash, he stops to be sure the victim emerges from the wreck. The same holds for a cocksure Jaguar XKE driver who overestimates his abilities when he challenges Kowalski to race. Under increasing pressure from the clock and the pursuing police, he can express genuine

CarCulture(s) Machines, Roads Mythologies gratitude to the outsiders who help him, like Dean Jagger's desertrat snake handler and the hippie motorcycle couple who enable him to slip yet another roadblock. Most importantly, in the longer UK-release version of the film, but unfortunately cut from its US equivalent, Kowalski shows that he can still crack a mellow smile

8. For example, his bemused attitude toward the Jesus-freak commune led by Mr. J. Hovah (Severn Darden), including the country-rock collective Delaney \& Bonnie \& Friends, who enjoyed a brief charge of celebrity thanks to their association with "Layla"-era Eric Clapton.

9. The accident image becomes even more uneasy if it anticipates the Elias Koteas character in David Cronenberg's Crash (1996)-from the novel by J.G. Ballard-for whom no car crash can be violent or erotic enough. While there is nothing erotic in Kolwalski's relationship with his Dodge Challenger, it is the only palpable connection he appears to have in the film's 'real' time. 
as he shares a midnight joint with Charlotte Rampling's mysterious hitchhiker-if that encounter in fact takes place. ${ }^{10}$

Kowalski works for a car delivery service in Denver. Dropping off a car on a Friday night he immediately requests another drive which the owner-against his better judgement-provides him. The car is a white Dodge Challenger Magnum R/T 400, one of the breed of muscle cars that returned a multi-barreled, four-on-the-floor riposte to Ralph Nader's 1965 exposé of the American automobile industry Unsafe at Any Speed. ." While they responded to consumer pressures by producing a generation of uninspired, underpowered sedans and station wagons, America's automobile manufacturers were not about to give up the market segment for whom cubic inches and horsepower still mattered most. The result was a fleet of mid-sized vehicles stuffed with maximum horsepower engines-Dodge Chargers, Plymouth Barracudas, Pontiac GTOs, Oldsmobile 442s, and many more. The Dodge Challenger that Kowalski drives, with a $350 \mathrm{hp} \mathrm{V}-8$ and a 13.5 second quarter-mile time, is definitely on that list. Fueling up with a load of Benzedrine tablets from his local drug dealer, Kowalski wagers that he can get the Challenger to San Francisco by three o'clock the next day, roughly fifteen hours of non-stop driving time. If he wins the bet, the Benzedrine is free; if he does not, he pays double for the next round. By Saturday morning he has crossed into Utah and has picked up a police tail. As his rate of progress accelerates and the folly of trying to haul him down becomes apparent, the Utah police have to hand him over to their Nevada counterparts-although it is not clear why he is being chased in the first place. There is no warrant for a stolen car, and the most the police can throw at him are charges of dangerous driving and failing to heed a stop sign, both misdemeanors. "Maybe he killed someone," one cop speculates. At the same time Kowalski has acquired a kindred spirit, the blind hyperkinetic deejay Super Soul (Cleavon Little),

10. Omission of the sequence with Charlotte Rampling in the American release has been argued to alter the film's narrative, leaving it incomplete and its conclusion seemingly incomprehensible by any 'normal' logic (see Dixon 2014). 11. The choice and the specifications of the Dodge Challenger-at least five were used in making the film, in various states of tune and with modified frames and suspensions-have generated a sizeable literature of their own (see, e.g., Zazarine 1986). 
who broadcasts from station KOW and follows his adopted hero's trajectory by eavesdropping on the police channel. From Super Soul's running commentary Kowalski learns crucial bits of information about the dragnet being cast around him; the disk jockey in turn believes he is communicating telepathically with the renegade driver, "the super driver of the golden west... the last beautiful free soul on this planet."

Critics have differed on Kowalski's decision to floor the accelerator and plow into the twin bulldozers that constitutes the film's spectacular conclusion. One interpretation sees it as his final, and inevitable, repudiation of a regime of regulation and surveillance-symbolized by the stop signs he ignores and the electronic trip wires by which the police monitor his movements-that has turned "the golden west" into a wasteland of mindless conformism and self-absorbed alienation. In Zabriskie Point Mark drives his pick-up truck through the industrial slums of East LA where everything around him points to a consumerist society that has run out of gas. In Vanishing Point Kowalski encounters the detritus of its no less exhausted alternative, the hippie-commune-drop out world that two years earlier had produced the Manson Family. The police who harass Kowalski with helicopters and roadblocks are a nuisance at worst, easily outwitted and almost as easily outdriven; they are not sociocultural adversaries. In fact, Kowalski is closer in ethos to the cops who pursue him than to the desert dwellers, religious fanatics, and potheads he meets each time

CarCulture(s) Machines, Roads Mythologies he veers off the highway. Another reading of the film has it that Kowalski has literally reached the end of the road. With nothing left but cars, drugs, and a paycheck at the end of each run, he goes instead for the one last way out, aiming at the sun-filled aperture between the bulldozer blades just as he has jumped construction barriers, bridge washouts, and police roadblocks in one long Benzedrine rush-the superman outlaw gesture at a time when neither supermen nor outlaws any longer make much sense.

Viewing the film with the seven or eight minutes with Charlotte Rampling included allows an altogether different interpretation to Kowalski's final decision, one that director Richard Sarafian intended. Telling Kowalski, "I've been waiting for you a long time, oh how l've waited for you," Rampling's hitchhiker is the alle- 
gorical figure of death or at the least one of death's messengers. Any seasoned art house viewer would at once have recognized the allusion to the Maria Casarès character in Jean Cocteau's Orphée (1950), which with its black limousine and motorcycleriding messengers is itself a kind of road movie. Already a favorite among cineastes for her previous films in England and Italy, especially Luchino Visconti's The Damned (1969), Rampling added an intellectual if not philosophical dimension to what otherwise would have seemed Kowalski's pointless cannonball run across the desert. In a 2009 interview Sarafian explained Rampling's function: "Symbolizing death and warning him that where we are now in our existence here is an absurd bind. I mean, we're all moving through this dimension at our own speed, some of us, like Kowalski, faster than the others, you know, on to another level. That's how I thought in terms of his ultimate so-called demise, and that in terms of him moving on and to another plane" (Kenny). In an interview twenty years earlier, Barry Newman attributed the same meaning to Kowalski's encounter with the Charlotte Rampling character: "She was the symbol of death. That was an interesting scene, because it really gave the film an allegorical lift and explains everything." "That's the allegorical thing in this film," Newman continued,"-that Kowalski was going to get through those bulldozers. He smiles as he rushes to his death at the end of Vanishing Point because he believes he will make it through the roadblock. Deep down, Kowalski may have believed he wasn't going to make it, but that's the basis of an existentialist film" (Zazarine 1986).

"AT LEAST SOMEONE WILL KNOW I TRIED"-

BEN SHOCKLEY TO GUS MALLY, IN THE GAUNTLET

Enjoying neither cult film status nor the allure of a film maudit, The Gauntlet does not rank high in most accountings of Clint Eastwood's oeuvre (see, e.g., Kirschner 2018: 66-67). Nonetheless, it was recognized by the Museum of Modern Art in 2008 for its jazz-infused score and was included in the British Film Institute's retrospective on Eastwood's early directorial career in the same year (Vaux 2012: 131). Taking the familiar Western theme of a lawman bringing in a fugitive-in this case a witness-and updating it to the post-Vietnam, 
CarCulture(s) Machines, Roads Mythologies

post-Watergate era, Eastwood created an alternative to his 'Dirty Harry' character, no less prone to verbal violence and almost equally quick on the draw, but capable of recognizing when he is in over his head whether in relation to his adversaries or to the low-life prostitute he is escorting, who turns out to be anything but.12 Ben Shockley, a washed-up and not-too-bright member of the Phoenix police department, is ordered to travel to Las Vegas to bring back "a nothing witness for a nothing trial" named Gus Mally. The witness in question turns out to be Augustina Mally (Sondra Locke), a foul-mouthed graduate of New York's prestigious Finch College who knows too much about the sexual peccadilloes of Shockley's boss, the Phoenix police commissioner (William Daniels). It takes some time for Shockley to realize that he and his witness are not expected to make back it to Phoenix, although a bomb-rigged car and a ferocious SWAT team assault on Mally's Las Vegas house, causing the structure to collapse in a bullet-riddled heap, slowly bring him to his senses. ${ }^{13}$

Rather than its set-piece pyrotechnics, which occur in the same sequence as sex acts in a porn film and with the same increasing intensity, most critics of The Gauntlet have focused on the personal dynamics between Eastwood's Shockley and Locke's Mally, complicated as they were by the actors' adulterous off-screen relationship (see, e.g., Alpert 1979). On the face of it, the growing attachment between a mob-connected hooker with a price on her head and a burned-out cop who, his guard let down, admits to having joined the police because "it seemed like an honest job," makes little sense. But in a reversal of his usual macho persona, Eastwood's slow-to-catch-on Shockley has to admire Mally's take-charge attitude, as well as her dexterity with a handgun and her readiness to endure the rapist advances of two bikers so that Shockley can free himself and regain control of their situation. In a surprising, for Eastwood, soft-focus motel room scene-although we saw something similar

12. Eastwood had already modernized the lawman/fugitive theme in 1968's Coogan's Bluff, directed by Don Siegel, where he pursues his quarry through the canyons of Manhattan.

13. In a 1984 interview Eastwood acknowledged that the shoot-out at Gus Mally's house was patterned on the 1974 police assault on the Los Angeles hideout of the Symbionese Liberation Army (SLA), responsible for the kidnapping of Patty Hearst, in which six people died (Wilson 2013: 88). 
in Play Misty for Me (1971)-the two share reveries of the life they would like to lead, "a piece of land near the Canyon," trees, horses, kids. And while it is Shockley who contrives the scheme by which he will complete his assignment, to deliver the witness alive to the Phoenix police headquarters, it is Mally who puts a bullet in the police commissioner who has set them up for execution in order to protect his position and his ties to the mob.

In the film's eponymous conclusion, Eastwood, back to his t-shirted, clenched-jaw self, retakes command. Hijacking a bus and reinforcing the driver's compartment with quarter inch-thick steel plates, Shockley and Mally make a slow-motion drive through the streets of Phoenix as half the city's police force pump 8,000 pistol, rifle, and shotgun shells into the vehicle. The cops apparently have no compunction in firing on one of their own, nor do any of them seem able to recognize that their massed firepower fails to impede the bus's progress to its destination. In the final frames, bloodied but vindicated, Shockley walks away, arm-in-arm with Mally, from the wrecked bus and the crowd of perplexed cops, presumably to find that place near the Canyon. But the one gesture of redefinition we look for however many times we see the film remains missing-Shockley removing his shield and tossing it on the ground. We would almost swear that he does it; yet he does not, at least not in this film. It would certainly appear that Shockley has reached theend of his existential road (Grossman2017: 48-49). ButEastwood had more police dramas left in his belt; perhaps it was better to end this one on a note of ambiguity rather than resolution. As has been observed, moral complexity and ambiguous relationships between principled individuals and powerful institutions have characterized some of Eastwood's best work as a filmmaker (Allison 2003).

Even before The Cauntlet was released, Eastwood and Locke were living together in a common-law marriage-he divorced his wife of twenty-five years in 1978-during which the actress appeared in four more films with him and directed two films of her own. When the relationship cooled, and after two abortions Eastwood allegedly insisted on, Locke filed a \$70 million palimony suit in 1989 claiming that she had put her career on hold to tend to the couple's domestic needs. The suit was settled out of court, with Locke receiving a three-year \$1.5 million package to develop and direct films 
for Warner Brothers. None of Locke's films materialized, and in 1995 she sued Eastwood a second time alleging that the Warner Brothers deal had been a fraud designed to kill the palimony suit. The case came to trial in 1996 in the full glare of scandal-driven publicity, with Eastwood again agreeing to settle rather than risk a jury verdict (McGilligan 2002: 444-465, 519-522). Ben Shockley may have thought he was through with law enforcement, but the law was definitely not through with him; at the University of California the litigation between Sondra Locke and Clint Eastwood is still being used to teach contract law (Knapp 2013; see also Sterritt 2014: 234-37).

\section{CONCLUSION}

In his study of the Mediterranean world over a long expanse of centuries, Fernand Braudel observed that the mountain ranges ringing the sea had first been-and long remained-the refuge of bandits, fugitives, and heretics (1972: 31-43). Descending into the lower altitudes could be dangerous, and eventually the inhabitants of those nether regions made their way into the once remote spaces that towered above them. In the three films considered here, mountains provide no refuge. In Zabriskie Point, Daria's arrival at the mountainside home of her employer provides the final confirmation of her alienation from the world it represents-and the world that has killed Mark. The guests who enjoy sitting poolside and sipping drinks are no less artificial than their

CarCulture(s) Machines, Roads Mythologies surroundings, and their illusion of glamour and sophistication is equally plastic. They could easily have appeared in the billboard advertisements that Mark saw in the scrum of Los Angeles as he drove to the airport, and they seem altogether deserving of the obliteration they are about to experience. In Vanishing Point and The Gauntlet, the trajectory is just the opposite. For both Kowalski and Shockley, the flatlands, the skein of highways that cross the Southwest, are the arena in which they fight their gladiatorial battles, Kowalski with speed-both kinds-and resourcefulness, Shockley with grim determination and a welding torch. Kowalski's Dodge Challenger is the one constant in Vanishing Point; for all the beating it takes, it never fails when called upon to perform another law-of-physics defying stunt and-as any enthusiast 
of the film knows-its collision with the bulldozer blades is in fact enacted by a Chevrolet Camaro on a tow chain. Surprisingly, given the film's enthusiastic following, Kowalski's Challenger never developed the allure-and the commercial value-of the Mustang 390 GT Fastback that Steve McQueen drove in Bullitt. When the Bullitt Mustang resurfaced in 2018, it made the rounds of historic car shows and a year later prompted Ford to release a Special Bullitt edition of its current Mustang line. Absent Steve McQueen's star power and without the kind of high-speed car chase that defined Bullitt, The French Connection, and-another decade later-William Friedkin's To Live and Die in L.A. (1985), the Challenger languishes as something of an orphan next to the long run of Hemi-powered Dodge Chargers.

Ben Shockley's and Gus Mally's journey from Las Vegas to Phoenix, fraught as it is with betrayals and traps, employs multiple conveyances-a police car, a motorcycle, a train, and an armored bus. Only the last acquires an anthropomorphic identity when, having reached its destination at the Phoenix City Hall, it exhales a final gasp of exhaustion-the bullet-shredded tires finally give outcomparable to that of its driver, who is literally at the end of both his road and his rope. While they serve their respective purposes, neither Daria's tired Buick sedan-itself a kind of reference point to the downbeat small-town movies of the first post-World War II years-nor Shockley's and Mally's hijacked bus have any particular cinematic presence that would allow it to play the dominating role that Kowalski's Challenger does for the entire running time of Vanishing Point. If the template for the modern American road movie was established by Easy Rider, some kind of an apocalyptic conclusion should be expected to figure in the protagonists' arrival at-or failure to arrive at-their predicated destination. Certainly, this is the case in Vanishing Point, whether we interpret Kowalski's collision with the bulldozers as a moment of exhilarating liberation or, to quote one British reading of the film, an act of "suicidal resignation" (Ward 2012: 197). Kowalski's world, or at least as much of it as we are permitted to see, consists of all-night garages, drug deals, and an ever-receding horizon where nothing but more of the same awaits. The alternatives the desert presents him, the artifacts of the counterculture-blondes on motorcycles, mystical excess, 
religious hysteria-are even less attractive. The same dead end confronts Mark in Zabriskie Point. Still on the run, fearing that he is implicated in the shooting of a cop during a campus demonstration and turned off from the hippie lifestyle he has sampled with Daria, Mark has no choice but to look for a way back into the hanger-on world of Southern California campuses, however boring he finds its politics. While we can code Mark as another victim of triggerhappy cops, Daria's transformation is more profound. No longer a dope-smoking office temp who may be having an affair with her boss, Daria's vision of the exploding desert mansion-even if a fantastic product of her imagination-betrays a complete repudiation of the lifestyle she has to this point at least minimally participated in, either tolerating or ignoring. Antonioni's dialectic tension between a predatory late capitalism, Los Angeles-style, and the counterculture ethos of anti-materialism and love-ins may be muddled at best or even, as has been argued, self-contradicting (Sieving 2016). But Daria's allegiances in the film's final frames are hardly confused. There is something apocalyptic about ramming a cross-country bus halfway up the steps of the Phoenix City Hall, even if the point is simply to deliver a "nothing witness for a nothing trial." Having survived a fusillade of anonymous police bullets that goes on for several city blocks, and then a close-range personalized attempt on his life, Ben Shockley appears to have achieved the equipoise he described in his motel room confessional to Gus Mally-an honest cop, doing the right thing, with a new girlfriend

CarCulture(s) Machines, Roads Mythologies who has $\$ 5,000$ in the bank; existential definition, redefined.

Whether conceived as a genre, a convention, or simply a staple of the drive-in circuit, the road movie depended on the diegetic and extra-diegetic sensations it delivered-the throb of a largedisplacement $\mathrm{V}$-8; the smell of gasoline, exhaust, and burning rubber; the oncoming rush of the open road and its equally evanescent recession in the rear-view mirror; endless possibility compressed into a single metal pedal when it was pushed to the floor. The American car culture of the 1960s and 1970s-of which the road movie was an emblematic component-has largely become a thing of the past. The muscle cars of the era continue to attract enthusiasts to car shows and draw impressive bids at Mecum auctions, and, as a kind of evolutionary descendant the Fast and Furious franchise, now ten 
years in, shows no sign of exhausting itself. The market appetite for Camaros and Chargers and Mustangs remains healthy, however anachronistic these models might seem. But when everything in the theaters is played as archetype or stereotype, there is little opportunity for individual self-definition, whether existentialist or of any other kind. In fact, the metrics of filmmaking today prohibit the kind of studio risk-taking represented by Zabriskie Point or Vanishing Point. Even Gran Torino (2009), which made Clint Eastwood-as Walt Kowalski-the cantankerous owner of a 19725.7 liter Cobra Jet V-8-powered namesake vehicle, fails to fit the template of the road movie; there is, after all, no road in the film. With electric vehicles the wave of the present, with SUVs outselling sedans by multiple orders of magnitude, and with engine governors being emplaced in computerized control systems on an accelerating basis, car culture itself may already be a thing of the past (see, e.g., Stoner 2020; Haggerty 2021). 
WORKS CITED

Alford, Steven E. "Easy Riders Lost in America: Marx, Mobility, and the Hollywood Road Movie." Class, Race, and Corporate Power 6, no. 2, 2018. https://digitalcommons.fiu.edu/classracecorporatepower/vol6/iss2/1. Accessed 03 Mar. 2021.

Allison, Deborah. "Great Directors: Clint Eastwood." Senses of Cinema, no. 28, 2003. http://sensesofcinema.com/2003/great-directors/ eastwood. Accessed 03 Mar. 2021.

Alpert, Robert. "The Gauntlet: Eastwood Plays Dumb Cop." Jump Cut: A Review of Contemporary Media, no. 20, 1979, pp. 3-5. http:// www.ejumpcut.org/archive/onlinessays/JC20folder/Gauntlet. html. Accessed 03 Mar. 2021.

Archer, Neil. The Road Movie: In Search of Meaning. Wallflower Press, 2016.

Beck, John. "Resistance Becomes Ballistic: Vanishing Point and the End of the Road." Cultural Politics 3, no. 1, 2007, pp. 35-50.

Behlil, Melis. "Zabriskie Point (1970), Michelangelo Antonioni, and European Directors in Hollywood." The Hollywood Renaissance: Revisiting American Cinema's Most Celebrated Era, edited by Peter Krämer and Yannis Tzioumakis. Bloomsbury, 2018, pp. 149-164.

Biskind, Peter. Easy Riders, Raging Bulls: How the Sex, Drugs, and the Rock ' $n$ ' Roll Generation Saved Hollywood. Simon \& Schuster, 1998.

CarCulture(s) Machines, Roads Mythologies

Bodroghkozy, Aniko. "Reel Revolutionaries: An Examination of Hollywood's Cycle of 1960s Youth Rebellion Films." Cinema Journal 41, no. 3, 2002, pp. 38-58.

Borden, Iain. Drive: Journeys through Films, Cities, and Landscapes. Reaktion Books, 2012.

Braudel, Fernand. The Mediterranean and the Mediterranean World in the Age of Philip II. 1949, vol 1. Translated by Siân Reynolds. Harper \& Row, 1972.

Cohan, Steven and Ina Rae Hank, editors. The Road Movie Book. Routledge, 1997.

Dixon, Wheeler Winston. "Missing in Action: The Lost Version of Vanishing Point." Film International, 03 March 2014. http://filmint. nu/?p=10904. Accessed 28 Feb. 2021. 
Duarte, José and Timothy Corrigan, editors. The Global Road Movie: Alternative Journeys around the World. Intellect, 2018.

Gandy, Matthew. "The Cinematic Void: Desert Iconographies in Michelangelo Antonioni's Zabriskie Point." Landscape and Film, edited by Martin Lefebvre. Routledge, 2006, pp. 315-322.

The Gauntlet. Directed by Clint Eastwood. Warner Brothers. 1977. Warner Brothers DVD, 2005.

Godfrey, Nicholas. The Limits of Auteurism: Case Studies in the Critically Constructed New Hollywood. Rutgers University Press, 2018.

Grossman, Andrew. "Welcome to the Ranks of the Disenchanted: Feminism and Pacifist Spectacle in The Gauntlet." Clint Eastwood's Cinema of Trauma: Essays on PTSD in the Director's Films, edited by Charles R. Hamilton and Allen H. Redmond. McFarland, 2017, pp. 37-52.

Haggerty, McKeel. "Can Car Culture Survive Self-Driving Vehicles?" No Parking podcast. January 21, 2021. https://www.youtube. com/watch?v=cKxtWmiB8oo. Accessed 10 Nov. 2021.

Hurault-Paupe, Anne. "The Paradoxes of Cinematic Movement: Is the Road Movie a Static Genre?" Miranda 10, no. 25, 2014. https://journals.openedition.org/miranda/6257. Accessed 10 Nov. 2021.

Kenny, Glenn. "Dodge Challengers and Möbius Strips: Director Richard C. Sarafian on Vanishing Point." Some Came Running web site (22 February 2009). http://somecamerunning.typepad. com/some_came_running/2009/02/dodge-challengers-andm\%[3\%B6bius-strips-director-richard-c-sarafian-on-vanishing-point.html. Accessed 28 Feb. 2021.

Kirschner, Jonathan. “'A Man's Got to Know His Limitations': The Cop Films from Nixon through Reagan." Tough Ain't Good Enough: New Perspectives on the Films of Clint Eastwood, edited by Lester D. Friedman and David Desser. Rutgers University Press, 2018, pp. 55-74.

Knapp, Charles L. "Cases and Controversies: Some Things to Do with Contracts Cases" (2013). http://papers.ssrn.com/sol3/Papers. cfm?abstract_id=2392404. Accessed 10 Mar. 2021.

Laderman, David. Driving Visions: Exploring the Road Movie. University of Texas Press, 2002. 
Lamberti, Edward. "Forced into Heroism: Clint Eastwood's Reluctant Protagonists in The Eiger Sanction, The Gauntlet, and Firefox." The Films of Clint Eastwood: Critical Perspectives, edited by Matt Wanat and Leonard Engel. University of New Mexico Press, 2018, pp. 29-47.

Lie, Sulgi. "Absorption and Utopia: Mapping the Sixties in Antonioni's Zabriskie Point." Revisiting the Sixties. Interdisciplinary Perspectives on America's Longest Decade, edited by Laura Bieger and Christian Lammert. Campus, 2013, pp. 261-278.

McGilligan, Patrick. Clint: The Life and the Legend. St. Martin's, 2002.

Melbye, David. Landscape Allegory in Cinema: From Wilderness to Wasteland. Palgrave Macmillan, 2010.

Pascoe, David. "Vanishing Points." Autopia: Cars and Culture, edited by Peter Wollen and Joe Kerr. Reaktion Books, 2002, pp. 75-82.

Pomerance, Murray. Michelangelo Red, Antonioni Blue: Eight Reflections on Cinema. Berkeley: University of California Press, 2011.

Restivo, Angelo. "Revisiting Zabriskie Point." Antonioni: Centenary Essays, edited by Laura Rascaroli and John David Rhodes. Palgrave Macmillan, 2011, pp. 82-97.

Sargeant, Jack and Stephanie Watson, eds. Lost Highways: An Illustrated History of Road Movies. Creation Books, 1999.

Sieving, Christopher. "The Man Can't Bust Our Movies: Buying and Selling the Counterculture with Zabriskie Point (1970)." The Sixties:

CarCulture(s) Machines, Roads Mythologies A Journal of History, Politics, and Culture, vol 9, no. 2, 2016, pp. 218-241.

Sterritt, David. The Cinema of Clint Eastwood: Chronicles of America. Wallflower Press, 2014.

Stoner, Dan. "The Future of Cars Is in the Culture." Hemmings Motor News, September 3, 2020. https://www.hemmings.com/ stories/2020/09/03/the-future-of-cars-is-in-the-culture. Accessed 10 Nov. 2021.

Thomas, Deborah J. "Traversing Genre: The Australian Road Movie." Australian Genre Film, edited by Kelly McWilliam and Mark David Ryan. Routledge, 2021, pp. 122-137.

Tweedle, Sam. "Return to Zabriskie Point: The Mark Frechette and Daria Halprin Story." Confessions of a Pop Culture Addict (May 2010). 
http://popcultureaddict.com/movies-2/zabriskiepoint-htm. Accessed 28 Feb. 2021.

Vanishing Point. Directed by Richard C. Sarafian. Cupid Productions. 1971. Twentieth Century Fox DVD, 2003.

Vaux, Sara Anson. The Ethical Vision of Clint Eastwood. Wm. B. Eerdmans Publishing, 2012.

Villella, Finoa. "Here Comes the Sun: New Ways of Seeing in Antonioni's Zabriskie Point." Senses of Cinema, no. 3 (March 2000), republished no. 74 (March 2015). http://sensesofcinema.com/issues/ issue-74. Accessed 28 Feb. 2021.

Ward, Simon. “'Danger Zones': The British 'Road Movie' and the Liminal Landscape." Liminal Landscapes: Travel, Experience, and Spaces In-Between, edited by Hazel Andrews and Les Roberts. Routledge, 2012, pp. 185-199.

Wilson, Michael Henry. “'Whether I Succeed or Fail I Don't Want to Owe It to Anyone but Myself': From Play Misty for Me to Honkytonk Man." Clint Eastwood: Interviews, Revised and Updated, edited by Robert E. Kapsis and Kathie Coblentz. University of Mississippi Press, 2013, pp. 72-92.

Zabriskie Point. Directed by Michelangelo Antonioni. MGM. 1970. Warner Brothers DVD 2009.

Zazarine, Paul. "Behind the Scenes of the Movie Vanishing Point." Muscle Car Review, 1986. http://www.angelfire.com/id/newssection/ VP.html. Accessed 28 February 2021.

Zendy, Peter. "The Archi-Road Movie." Senses a Society 8, no. 1, 2013, pp. 50-61. 
